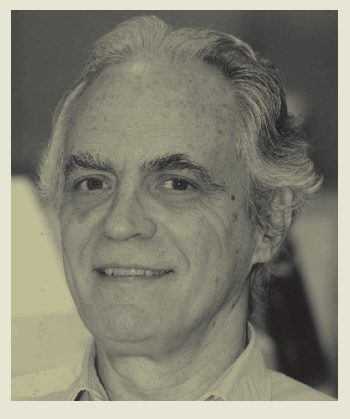

\title{
UM BEIJO IMPROVÁVEL
}

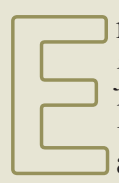
ncantadores de serpentes não ousam beijar uma cascavel. Alguns economistas, militando no governo federal, no entanto, acham que é possível. Ou melhor, achavam.

Advertidos pelo barulho crescente do chocalho do rebaixamento do rating soberano, eles resolveram recuar. Talvez um pouco tarde. O fato é que causaram tantas distorções nas taxas básicas da economia - câmbio, juros, impostos e salários - que desorientaram os investidores tupiniquins e tupinambás. Sem eles, será difícil a retomada do crescimento econômico.

Nos três últimos anos de mandato da atual Presidente, a indústria perdeu cerca de 200 mil empregos, o superávit comercial foi reduzido a quase zero, a produtividade estancou, a competitividade dos exportadores desmoronou (com exceção das commodities agrícolas e metálicas) e a credibilidade externa sofreu forte abalo.

O lado positivo dessa política: o nível de emprego se manteve ou até aumentou pela expansão dos serviços (non tradables), os salários reais especialmente os mais baixos - cresceram, o nível de consumo se expandiu e a inflação, depois de um forte soluço no primeiro semestre, voltou a ficar como morcego, grudada no teto da meta, graças a algumas desonerações tributárias e retenções de preços controlados pelo governo.

Sabemos que essa política é insustentável. Percebendo a perda de confiança dos investidores, o governo tenta, lentamente, fazer um rearranjo das taxas. O câmbio começa a se desvalorizar, os juros (Selic) a crescer, as desonerações tributárias a desaparecer e os salários (leia-se salário mínimo) a acusar um aumento real muito baixo. Até as eleições de outubro, o governo federal espera ir empurrando com a barriga e rezando para que não ocorram as manifestações de descontentamento que marcaram 2013.

Mas e em 2015? Quem vencer em outubro terá de solucionar um problema reconhecido por todos: como recuperar o nível dos investimentos e voltar a crescer de forma expressiva? Pelo menos duas providências precisam ser tomadas: 1) acelerar a recomposição das quatro taxas mencionadas anteriormente, permitindo a sobrevivência da indústria, a retomada das exportações de manufaturados e o aumento da produtividade e 2) adequar a dívida pública, viabilizando o alongamento dos prazos de vencimento e a redução sustentável dos juros, visando uma liberação do garrote do superávit primário. Esse processo requer um período relativamente longo (pelo menos um mandato presidencial) e medidas que, nos primeiros anos, serão dolorosas: pressões inflacionárias e desemprego. Esse será o custo a pagar por um espetáculo que já vimos durante o primeiro mandato de FHC: para se reeleger, medidas econômicas necessárias, porém impopulares, não foram aprovadas. Depois de vencidas as eleições, o baú das maldades foi aberto e o que deveria ter sido feito antes a um custo muito menor saiu por um preço exorbitante: quatro anos de estagnação. 